\title{
Cultivo de pós-larvas de tilápia do Nilo utilizando diferentes proporções de substrato concha/brita no biofiltro*
}

\section{Post-larval culture of Nile tilapia with different ratios of calcareous shell/gravel substrate in biofilters}

\author{
Eglerson Duarte, ${ }^{* *}$ Marcelo Mattos Pedreira, ${ }^{* *}$ Alcione Eneida Santos, ${ }^{* *}$ Fernanda da Conceição Moreira, ${ }^{* * *}$ Naiara Cristina Motta ${ }^{* *}$
}

\begin{abstract}
Resumo
A avaliação da proporção ideal de concha calcária/brita em biofiltro no cultivo de pós-larvas de tilápia do Nilo foi o objetivo deste trabalho. O experimento foi realizado no Laboratório de Aquicultura e Ecologia Aquática da Universidade Federal dos Vales do Jequitinhonha e Mucuri - UFVJM, entre os dias 21 de julho a 3 de agosto de 2011. Pós-larvas de tilápia do Nilo na densidade de 13,3 pós-larvas/L foram cultivadas em aquários contendo biofiltros com $100 \%$ concha calcária; $70 \%$ concha calcária/30\% brita; $50 \%$ concha calcária $/ 50 \%$ brita; $30 \%$ concha calcária/ $70 \%$ brita; $10 \%$ concha calcária $/ 90 \%$ brita; $100 \%$ brita e como controle, aquário sem biofiltro, em DIC, totalizando sete tratamentos com três repetições. A presença de concha calcária no biofiltro proporcionou melhores condições da água, quando comparado com os aquários sem biofiltro e com brita apenas, mantendo os parâmetros adequados para o cultivo de tilápia do Nilo. Apesar dos níveis de amônia estarem próximos ao limite superior desejado para o cultivo da espécie, eles não comprometeram o crescimento (comprimentos total e padrão, altura e peso). A proporção $30 \%$ de concha calcária e $70 \%$ de brita é recomendada como substrato de biofiltro, por apresentar a melhor taxa de nitrificação ao longo do experimento.
\end{abstract}

Palavras-chave: biofiltração, larvicultura, nitrificação, resíduos nitrogenados, Oreochromis niloticus.

\begin{abstract}
The evaluation of the optimal ratio of calcareous shell/gravel substrate in biofilters was evaluated in post-larval culture of Nile tilapia the was objective of this work. The experiment was conducted at the Laboratory of Aquaculture, UFVJM University, Brazil, from July 21 to August 3, 2011. Post-larvae of Nile tilapia at density 13.3 post-larvae/L were grown in tanks containing biofilters with $100 \%$ calcareous shell; $70 \%$ calcareous shell $/ 30 \%$ gravel; $50 \%$ calcareous shell $/ 50 \%$ gravel; $30 \%$ calcareous shell $/ 70 \%$ gravel; $10 \%$ calcareous shell/ $90 \%$ gravel; $100 \%$ gravel; tank without biofilters and control, in completely randomized design with seven treatments and three repetitions. Calcareous shell provided better water conditions than tanks without biofilter or containing only gravel, keeping the parameters suitable for Nile tilapia farming. Although ammonia levels were close to the desired upper limit, they had no influence on morphological parameters (total length, standard length, height and weight). The rate $30 \%$ shell/70\% gravel is recommended as biofilter substrate, as it provided the best nitrification rate during the experiment.
\end{abstract}

Keywords: biofiltration, larviculture, nitrification, nitrogenous waste, fish farming, Oreochromis niloticus.

\section{Introduction}

Aquaculture growth is a permanent source of possible environmental impacts. Fish culture, like any other farming activity, produces effects on the environment either by spread of exotic species (Fernandes et al., 2003) or diseases (Maximiano et al., 2005) or effluents that increase water concentration of nutrients and sediments.

Because meat characteristics (Souza and Maranhão, 2001) and ease of adaptation to climate conditions in the country, the culture of Nile tilapia has been considered one of the main species for national expansion of fish farming (Mainardes-Pinto et al., 1989). For being a rustic fish that supports well the intense handling and offers great resistance to disease and low levels of dissolved oxygen, it adapts well to intensive cultivation systems.

Closed loop water systems are becoming alternatives for providing better water use and minimizing potential impacts (Pedreira, 2003; Pedreira and Ribeiro, 2008; Pedreira et al., 2009). In addition, biofilters allow for the establishment of nitrifying bacteria colonies which are responsible for decomposing organic waste material and thus ammonia is oxidized to nitrate (Kubitza, 2003).

\footnotetext{
* Recebido em 10 de novembro de 2012 e aceito em 14 de fevereiro de 2013.

** Departamento de Zootecnia - Universidade Federal dos Vales do Jequitinhonha e Mucuri - Rodovia MGT 367 - Km 583, $\mathrm{n}^{\circ} 5000$, Alto da Jacuba 39100-000 - Diamantina, MG. CEP 39100-000.

*** Departamento de Biologia - Universidade Federal de Lavras - Caixa Postal 3037, Lavras, MG. CEP 37200-000.

Autor para correspondência: Eglerson Duarte. E-mail: eglersonduarte@yahoo.com.br.
} 
An efficient process of nitrification depends on the substrate choice (Chen et al., 2006). Several types of substrates have been tested lately, especially calcareous shell and gravel. In shrimp farming, biofilters with calcareous shell improved water parameters and crushed shells have been effective at controlling and maintaining water alkalinity (Crivelenti et al., 2009). In addition, calcareous shell and gravel yielded satisfactory results in the larviculture of pacamã, as concentrations of ammonium ion were low in both internal and external biofilters (Pedreira et al., 2009). Also in larviculture of pacamã shell and gravel substrate showed a better nitrification and higher concentrations of nitrate (Pedreira and Ribeiro, 2008).

Biofiltration systems used in aquaculture have presented a variety of performance results. Defining the optimal substrate ratio to maintain acceptable water parameters is one of the challenges to biofilter assembly. Therefore was evaluated in this experiment the optimal ratio of calcareous shell to gravel in internal biofilters to maintain adequate water quality in post-larval culture of Nile tilapia.

\section{Material and methods}

The experiment was carried out in the Laboratory of Aquaculture and Aquatic Ecology of Universidade Federal dos Vales do Jequitinhonha e Mucuri - UFVJM, between July 21 to August 3, 2011.

The treatments consisted of biofilters submerged in tanks containing gravel (mean diameter $2.1 \mathrm{~cm}$ ) and calcareous shell (mean diameter $1.3 \mathrm{~cm}$ ) at different concentrations: 100\% calcareous shell (100C); $70 \%$ calcareous shell/30\% gravel (70C); $50 \%$ calcareous shell $/ 50 \%$ gravel $(50 \mathrm{C}) ; 70 \%$ calcareous shell $/ 30 \%$ gravel (30C); $10 \%$ calcareous shell/90\% gravel (10C); and $100 \%$ gravel (0C). Aerated tanks without biofilters (NB) were used as control. The system was divided into seven treatments and three repetition each, totaling twenty one experimental units in completely randomized design.

Thirty days before the experiment the substrate materials were washed in running water and decontaminated by sunlight for 24 hours. Then the substrates were placed in a $70 \mathrm{~L}$ polyethylene box with constant aeration $2.56 \mathrm{~m}^{3}$ air/min (water recirculation $0.48 \mathrm{~L} / \mathrm{min}$ ) and water temperature controlled by $150 \mathrm{~W}$ heaters with thermostats keeping minimum $32^{\circ} \mathrm{C}$ and maximum $34^{\circ} \mathrm{C}$. For maturation and fixation of nitrifying bacteria, $42 \mathrm{~g}$ of commercial diet with $55 \%$ crude protein were added to the water three times a week. The biofilter system comprised 0.4 $L$ polyethylene terephthalate containers $(13 \mathrm{~cm}$ height, $6 \mathrm{~cm}$ diameter) completely filled with substrates and closed at the top with $0.5 \mathrm{~mm}$ mesh screens to prevent post-larvae from entering the biofilters. Placed in the center of tanks, each biofilter had a PVC air lift tower (15 cm height, $2 \mathrm{~cm}$ diameter) emerging $1 \mathrm{~cm}$ above water level. Constant aeration $\left(0.96 \mathrm{~m}^{3}\right.$ air $\left./ \mathrm{min}\right)$ applied to the air lift tower provided water recirculation $0.18 \mathrm{~L} / \mathrm{min}$. In tanks without biofilters aeration was placed directly in water. Five days before settlement, filters were installed in tanks and heating and aeration devices were adjusted.

Post-larvae of Nile tilapia, 12 days hatching, mean length and standard deviation $11.554 \pm 0.825 \mathrm{~mm}$, mean body weight and standard deviation $19.00 \pm 0.004 \mathrm{mg}$ (average 20 post-larvae) from CODEVASF Company were stocked at density 13.3 postlarvae/L in 21 circular tanks with capacity of $6 \mathrm{~L}$, under average illuminance 350 lux achieved with natural photoperiod.
Post-larvae received $16 \%$ of their biomass $(0.12 \mathrm{~g})$ in commercial ration $55 \%$ crude protein (Pirá Alevino 55 Guabi) divided into four daily meals at $8 \mathrm{am}, 11 \mathrm{am}, 2 \mathrm{pm}, 5 \mathrm{pm}$. A bottle $(0.3 \mathrm{ml})$ was used as standard measure of feed in each tank. Once a day, after the first morning feeding, we siphoned the bottom of tanks to remove debris. Then the withdrawn volume, maximum $10 \%$, was immediately replenished. In addition, dead post-larvae were removed and quantified throughout the day.

Parameters for conductivity ( $\mu \mathrm{S} / \mathrm{cm}$ ) (using Corning CD-55), $\mathrm{pH}$ (using a portable $\mathrm{pH}$ measure Quimis $\mathrm{Q} 400 \mathrm{H}$ ), dissolved oxygen (mg/L) (using oximeter YSI 55), and turbidity (NTU) (using portable turbidimeter Digilab TB-1000P) were measured at days 1,7 , and 14 of culture at 9 am, before siphoning. Also, $80 \mathrm{~mL} /$ tank, water samples were collected and immediately frozen to determine concentrations of ammonium $\left(\mathrm{NH}_{3}-\mathrm{N}\right)$ by the Nessler method and nitrite $\left(\mathrm{NO}_{2}-\mathrm{N}\right)$ and nitrate $\left(\mathrm{NO}_{3}-\mathrm{N}\right)$ by the $\mathrm{N}$-(1-naphthyl)-ethylenediamine method (NTD) adapted from Standard Methods (APHA, 1998).

The tanks were maintained in water-bath with temperature controlled by heaters $(150 \mathrm{~W})$. Temperature was measured with mercury thermometer at $8 \mathrm{am}, 2 \mathrm{pm}$ and $5 \mathrm{pm}$ and maintained in the range $27-29^{\circ} \mathrm{C}$. The water used in the experiment was treated with 3 and $5 \mu \mathrm{m}$ filters and activated carbon, then stored in polyethylene box $(500 \mathrm{~L})$ with constant aeration and conductivity $12.3 \mu \mathrm{S} / \mathrm{cm}, \mathrm{pH} 6.67$, turbidity $1.5 \mathrm{NTU}$, levels of dissolved oxygen approximately $7.03 \mathrm{mg} / \mathrm{L}$, ammonia $0.10 \mathrm{mg} / \mathrm{L}$, nitrate and nitrite $0.00 \mathrm{mg} / \mathrm{L}$.

Biometric analysis was performed with two individuals randomly collected from each repetition on the seventh day to subsequent statistical analysis. On the fourteenth day 15 animals were collected from each repetition and fixed in $7 \%$ formalin. In each sampling the fish were anesthetized and killed by temperature shock (water at $4^{\circ} \mathrm{C}$ ). Measurements of standard length, total length and height were obtained with digital caliper (Digimess $100.179 \mathrm{I})$, accuracy $0.01 \mathrm{~mm}$. Weight was determined with analytical balance (Shimadzu Ay-220) accuracy $0.1 \mathrm{mg}$, and blotting paper was used to remove excess liquid from post-larvae before weighing.

Limnological and biometric data obtained at the end of the experiment were subjected to analysis of variance for all treatments, and means were compared by Duncan test with Statistical Analysis System - SAS (1995). Difference between means was deemed significant with $p \leq 0.05$. Treatments with different calcareous shell/gravel rates were compared by regression analysis with REG procedure in the SAS system (1995) at 5\% significance level.

\section{Results and discussion}

Oxygen concentration remained in the range suitable for Nile tilapia culture (Kubitza, 2000) with very slight variations throughout growing season (Figure 1) and no significant difference between treatments $(p>0.05)$. Thus, calcareous shell/gravel rate did not influence levels of dissolved oxygen, and the air-lift system kept the same aeration efficiency as the oxygenation directly applied into water column. These results agree with those obtained by Pedreira (2003); however, they differ from those by Pedreira and Ribeiro (2008), who found higher levels of dissolved oxygen in tanks without biofilters.

Tanks with calcareous shell based biofilters tended to have higher conductivity than tanks without biofilters $(p<0.05)$. This increased 
conductivity is due to the calcareous material in shells, which allows for bicarbonate ions and ionized salts to be released into the medium. Some other authors reported high conductivity levels related to high concentration of calcium carbonate (Rock and Rojas, 2004; Pedreira and Ribeiro, 2008). These results confirm our findings, as electrical conductivity indirectly assesses the availability of ions and nutrients in water.

Levels of $\mathrm{pH}$ did not change significantly $(\mathrm{p}>0.05)$ at day 7 . At day 14 the highest levels of calcareous shell $(100 \%$ calcareous shell and $70 \%$ calcareous shell $/ 30 \%$ gravel) had higher $\mathrm{pH}$ than tanks without biofilters or with $100 \%$ gravel substrate. However, all treatments maintained $\mathrm{pH}$ suitable for production, which increases comfort and growth of Nile tilapia (Boscolo et al., 2001). Calcareous shell provided high values and low variation of $\mathrm{pH}$ (7.5-7.9) (Crivelenti et al., 2009; Pedreira et al., 2009), while dissociation of calcareous shells is responsible for maintaining pH stability (Crivelenti et al., 2009).

Turbidity was lower in all tanks with biofilters. Suspended particles deposit on the substrate and decrease turbidity levels (Timmons et al., 2006; Sesuk et al., 2009) thus promoting fish welfare, as low turbid waters allow fish to see their food and prevent clogging of gills according to Baldisserotto (2002).

Tanks without biofilters had higher levels of ammonia; however, there was no significant difference between biofilters $(p>0.05)$ (Figure 1). Concentrations of ammonia in tilapia culture usually range from 0.004 to $4.95 \mathrm{mg} / \mathrm{L}$ (Cardoso Filho et al., 2010; Mercante et al., 2011), which match our results. These findings suggest that growing conditions were deemed acceptable in our experiment. Also, ammonia concentrations below $0.24 \mathrm{mg} / \mathrm{L}$ are suitable for tilapia culture (Kubitza, 2000). Ammonia levels found in tanks with shellbased biofilters were close to those suitable for tilapia culture, while levels in tanks without biofilters or containing only gravel were over the suitable range at 7 and 14 days of culture. Other works also observed a greater efficiency in the process of nitrification in aquariums with biofilter when compared to without biofilters (Ozório et al., 2004; Pedreira et al., 2009).

Nitrite is deemed an intermediate in the oxidation of ammonium to nitrate. At day 7 nitrite levels were higher in biofilters filled with $100 \%$ gravel substrate $(p>0.05)$. This showed that nitrification efficiency with gravel was slower than with calcareous shell, which had lower concentrations of nitrite. At day 14 biofilters containing lower rates of calcareous shell (10\% calcareous shell $/ 90 \%$ gravel; $30 \%$ calcareous shell/ $70 \%$ gravel); and $100 \%$ gravel had higher levels of nitrite $(p \geq 0.05)$. Biofilters consisting solely of large gravel particles have been showing higher concentrations of nitrite than filters with calcareous shell/gravel (Pedreira et al., 2009). Therefore the types of substrate and its specific surface area influence nitrification efficiency (Chen et al., 2006).

Nitrite levels found in our study are close to those in the range $0.01-0.10 \mathrm{mg} / \mathrm{L}$ found by Mainardes-Pinto and Mercante (2003) for Nile tilapia. As levels below $0.7 \mathrm{mg} / \mathrm{L}$ are lethal to many species of freshwater fish (Kubitza, 2003) our results most probably did not affect post-larval survival.

At day 7 the biofilter with calcareous shell rate above $30 \%$ showed the highest nitrate levels, whereas at day 14 the highest levels ( $p>0.05$ ) were provided by the $30 \%$ calcareous shell $/ 70 \%$ gravel. As treatments without biofilters and with $100 \%$ calcareous shell showed lower concentration of nitrate, nitrification rate was also lower. Despite the low concentration of nitrate in tanks without biofilters, it was similar to the concentration in the tank containing $100 \%$ calcareous shell, which indicates that part of the ammonium ion was converted to nitrate, so nitrification occurred in the water column. This is corroborated by Pedreira et al. (2009), who reported nitrate production in tanks without biofilters.

Although nitrates are not highly toxic to fish, they become potentially toxic in recirculating water systems since nitrification increases nitrate levels (Vinatea, 2004). In poorly aerated tanks, denitrification could cause fish death. In addition, the smaller the amount of ammonia, the faster the microorganisms consume the compound and convert it to nitrate (Andrade et al., 2010).

Based on regression analysis we could infer that, at day 7 , ammonia had the lowest concentration $(0.15 \mathrm{mg} / \mathrm{L})$ with $63.5 \%$ calcareous shell (Figure 2). This amount is suitable for growing tilapia because it is below toxic levels (Kubitza, 2000).

Also, at day 7 the percentage $73.75 \%$ calcareous shell provided one of the highest efficiency levels of nitrification process (Figure 2). The lowest nitrite level $(0.060 \mathrm{mg} / \mathrm{L})$ in this concentration was below the lethal level for many species of freshwater fish (Kubitza, 2003), thus confirming the satisfactory results of calcareous shell/gravel combination (Pedreira et al., 2009).

At day 14 , regression analysis for ammonia and nitrite showed no significance $(p>0.05)$.

At days 7 and 14, nitrate had maximum levels $7.59 \mathrm{mg} / \mathrm{L}$ and $5.76 \mathrm{mg} / \mathrm{L}$ in the concentrations $59.35 \%$ and $38.88 \%$ calcareous shell (Figure 2). These high values show higher efficiency of nitrification, as increasing levels of nitrate and decreased ammonia and nitrite levels.

These results suggest that high shell concentration allows for faster biofilter adaptation to nitrification, although biofilters with low concentration tend to equalize efficiency over time.

Association of ammonia levels with biological results (Table 1), in which survival and growth (length, height and weight) were similar between treatments with and without biofilters even with high concentrations of ammonia, suggests that ammonia levels had no apparent toxicity during the experimental period. This may be related to $\mathrm{pH}$ levels, which directly influence the potential toxicity of ammonia and to low toxicity of ammonium ion as well (Baldisserotto, 2002). In addition, gradual increase in ammonia concentration during farming allows for tilapia adaptation to higher ammonia levels. Red hybrid tilapia was able to tolerate ammonia concentrations around $6.6 \mathrm{mg} / \mathrm{L}$ for a 24-hour period, showing 50\% mortality (Kubitza, 2000).

Survival rate, biomass, and biometric measurements (total length, standard length, height and weight) showed no significant difference $(p>0.05)$ between biofilters at day 7 of culture (Table 1$)$. However on day 14 the biofilters containing $50 \%$ of calcareous shell/50\% gravel, $30 \%$ calcareous shell $/ 70 \%$ gravel, $10 \%$ calcareous shell/ $90 \%$ gravel and $100 \%$ gravel, tended to have a higher rate of survival. This fact directly influenced biomass, so this rate also tended to provide greater biomass at day 14 . Simultaneous increases in biomass levels and survival rates in tilapia culture were also reported (Boscolo et al., 2001; Meurer et al., 2003). However, some other studies on biofilters containing various substrates showed no significant difference in survival results (Rhida and Cruz, 2001; Pedreira et al., 2009).

In the aquaria biofilters containing a $30 \%$ calcareous shell/70 gravel, the post-larvae at day 14 tended to have higher levels of total length, standard length and weight. 

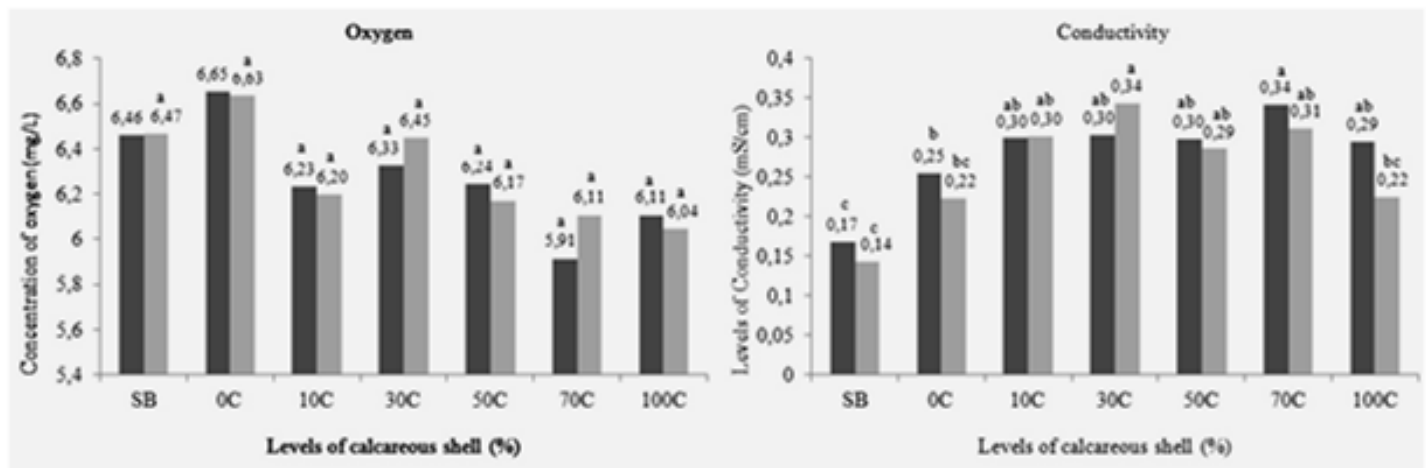

may 7 = Day 14

may 7 = Day 14
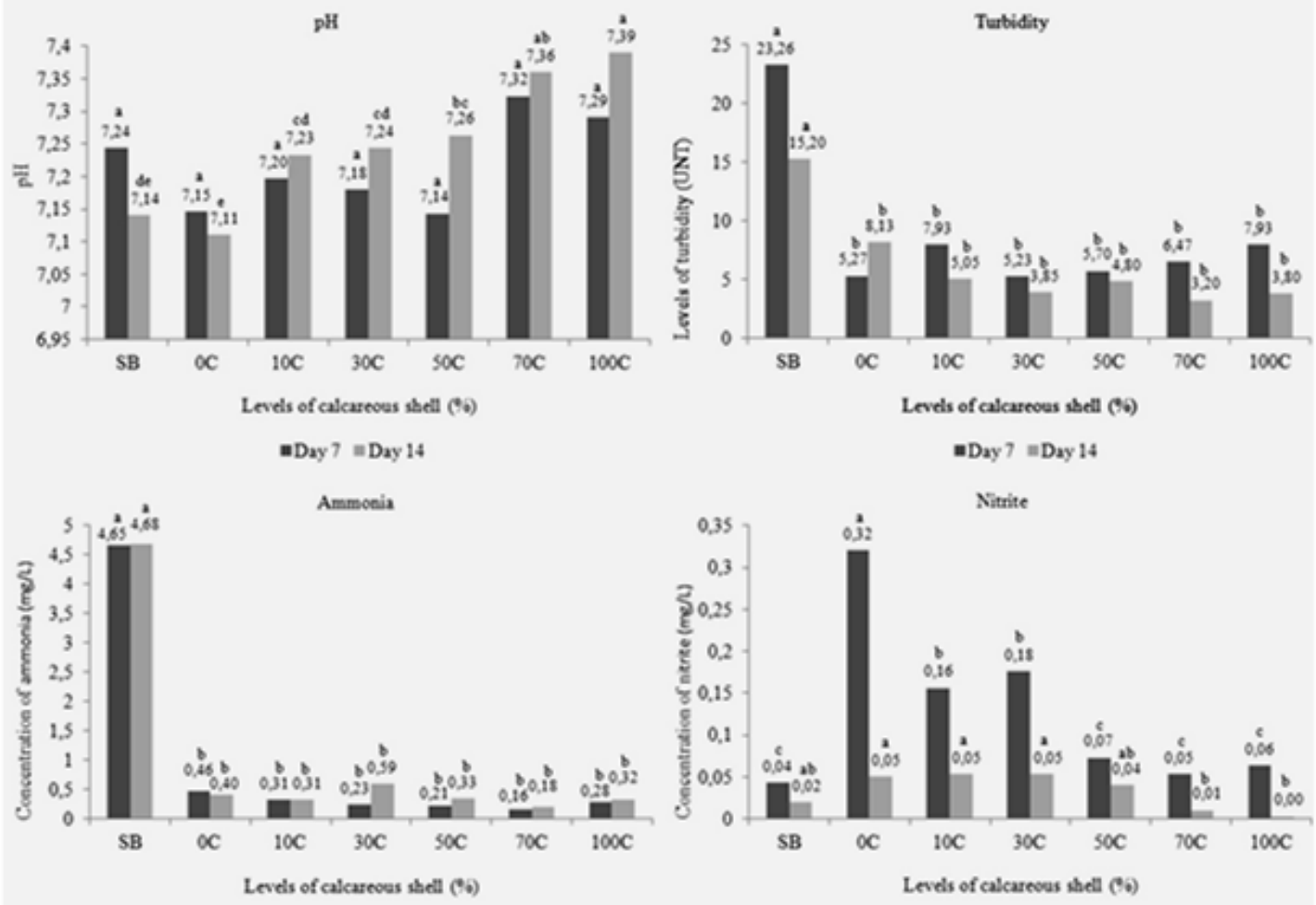

-Day 7 "Day 14

-Day 7 = Day 14

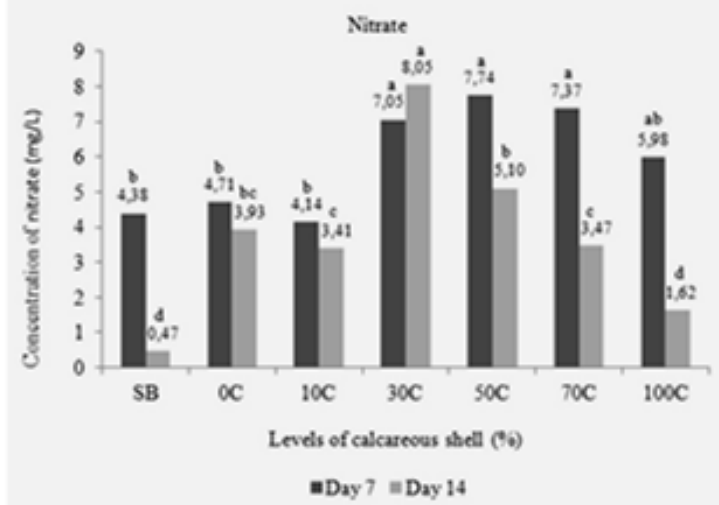

$100 \mathrm{C}=100 \%$ calcareous shell; $70 \mathrm{C}=70 \%$ calcareous shell $/ 30 \%$ gravel $; 50 \mathrm{C}=50 \%$ calcareous shell $/ 50 \%$ gravel; $30 \mathrm{C}=$ $30 \%$ calcareous shell $/ 70 \%$ gravel; $10 \mathrm{C}=10 \%$ calcareous shell $/ 90 \%$ gravel, $0 \mathrm{C}=100 \%$ gravel; NB $=$ no biofilter. Means in columns of same color followed by different letters differ by Duncan test $(p \leq 0.05)$.

Figure 1: Average levels of dissolved oxygen, conductivity, $\mathrm{pH}$, turbidity, ammonia, nitrite, and nitrate in culture water of post-larvae of Oreochromis niloticus at 7 and 14 days of culture using biofilters with different calcareous shell/gravel rates 

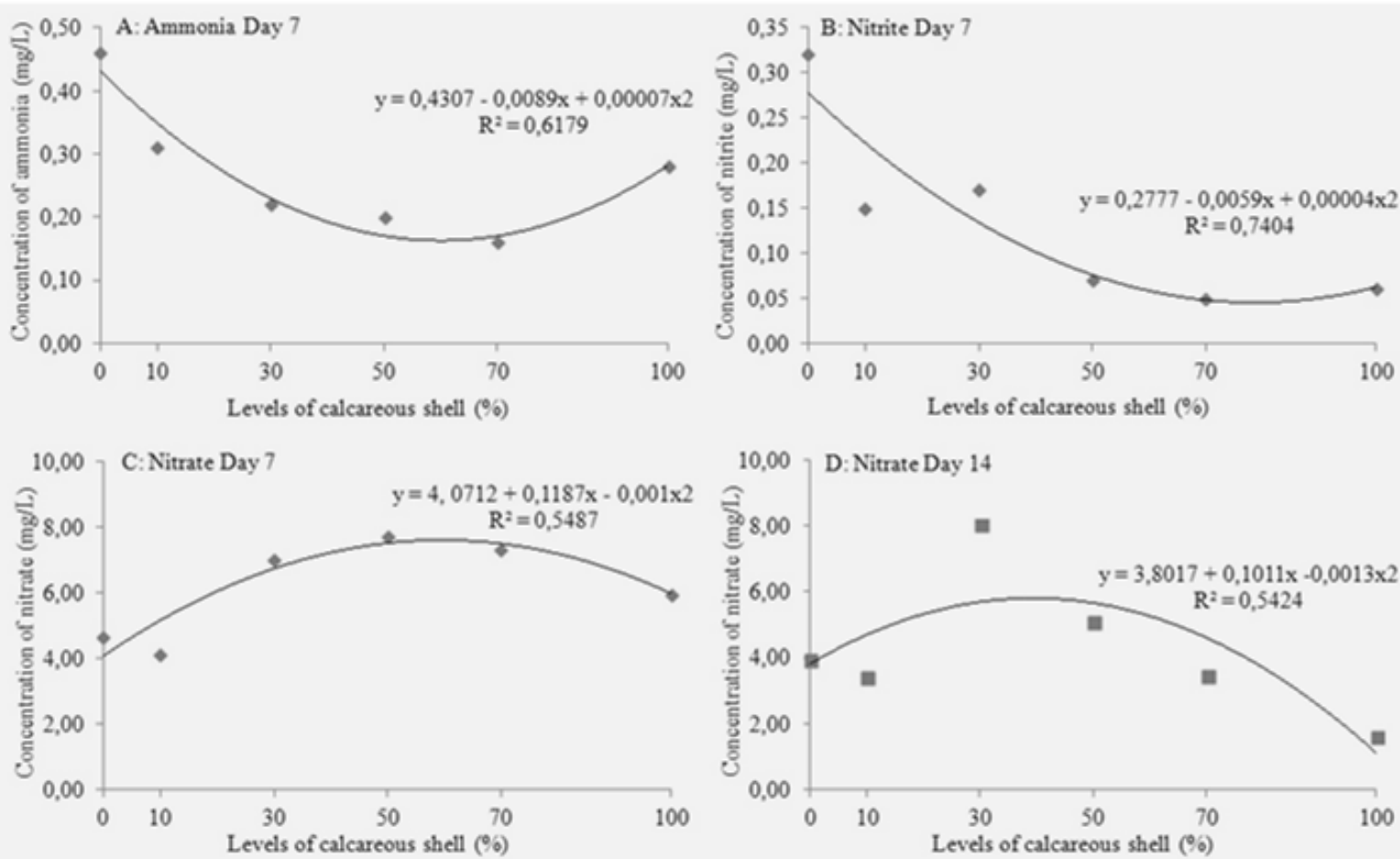

Figure 2: Regression between levels of calcareous shell and levels of ammonia (A) and nitrite (B) at day 7 . Levels of nitrate at 7 (C) and 14 (D) days of culture

Table 1: Mean values of survival (S), biomass (B), total length (TL), standard length $(\mathrm{SL})$, height $(\mathrm{H})$ and weight $(\mathrm{W})$ of post-larvae of Oreochromis niloticus at 7 and 14 days of culture using biofilters with different calcareous shell/gravel rates

\begin{tabular}{|c|c|c|c|c|c|c|}
\hline Substrate & S (\%) & $B(g)$ & $\mathrm{TL}(\mathrm{mm})$ & $\mathrm{SL}(\mathrm{mm})$ & $\mathrm{H}(\mathrm{mm})$ & W (mg) \\
\hline \multicolumn{7}{|c|}{ Day 7} \\
\hline $100 \mathrm{C}$ & $71.33^{a}$ & $2.229^{a}$ & $12.835^{a}$ & $10.200^{a}$ & $2.950^{a}$ & $31.33^{a}$ \\
\hline $70 \mathrm{C}$ & $78.33^{a}$ & $3.378^{a}$ & $13.633^{a}$ & $10.916^{a}$ & $3.016^{a}$ & $42.67^{a}$ \\
\hline $50 \mathrm{C}$ & $77.33^{a}$ & $2.742^{\mathrm{a}}$ & $13.221^{a}$ & $10.791^{a}$ & $2.795^{\mathrm{a}}$ & $35.67^{a}$ \\
\hline $30 \mathrm{C}$ & $83.00^{\mathrm{a}}$ & $4.101^{a}$ & $14.313^{\mathrm{a}}$ & $11.395^{a}$ & $3.103^{a}$ & $49.00^{a}$ \\
\hline $10 \mathrm{C}$ & $76.66^{a}$ & $1.926^{a}$ & $12.281^{a}$ & $10.021^{a}$ & $2.638^{a}$ & $25.33^{a}$ \\
\hline $0 C$ & $76.00^{a}$ & $2.900^{\mathrm{a}}$ & $13.543^{a}$ & $10.821^{a}$ & $2.901^{a}$ & $38.33^{a}$ \\
\hline NB & $78.33^{a}$ & $2.979^{a}$ & $13.253^{a}$ & $10.546^{a}$ & $2.875^{\mathrm{a}}$ & $38.00^{\mathrm{a}}$ \\
\hline CV (\%) & 8.64 & 42.80 & 8.73 & 7.79 & 11.81 & 38.44 \\
\hline \multicolumn{7}{|c|}{ Day 14} \\
\hline $100 \mathrm{C}$ & $21.333^{c}$ & $0.950^{\circ}$ & $14.289^{b}$ & $11.544^{b}$ & $3.407^{b}$ & $43.66^{b}$ \\
\hline $70 \mathrm{C}$ & $34.667^{\mathrm{b}}$ & $1.662^{\mathrm{bc}}$ & $14.481^{\mathrm{ab}}$ & $11.472^{\mathrm{b}}$ & $3.585^{\mathrm{ab}}$ & $45.66^{b}$ \\
\hline $50 \mathrm{C}$ & $52.00^{a}$ & $3.206^{a}$ & $15.386^{\mathrm{ab}}$ & $12.259^{\mathrm{ab}}$ & $3.845^{\mathrm{a}}$ & $61.66^{\mathrm{ab}}$ \\
\hline $30 \mathrm{C}$ & $60.33^{a}$ & $4.103^{a}$ & $15.666^{a}$ & $12.469^{a}$ & $3.946^{\mathrm{a}}$ & $67.66^{a}$ \\
\hline $10 \mathrm{C}$ & $51.33^{a}$ & $2.945^{\mathrm{ab}}$ & $15.032^{\mathrm{ab}}$ & $12.028^{a b}$ & $3.896^{a}$ & $56.66^{\mathrm{ab}}$ \\
\hline $0 \mathrm{C}$ & $59.00^{\mathrm{a}}$ & $3.104^{\mathrm{ab}}$ & $15.182^{\mathrm{ab}}$ & $12.300^{\mathrm{ab}}$ & $3.625^{\mathrm{ab}}$ & $52.66^{\mathrm{ab}}$ \\
\hline NB & $47.333^{\mathrm{ab}}$ & $2.723^{\mathrm{ab}}$ & $15.325^{\mathrm{ab}}$ & $12.212^{\mathrm{ab}}$ & $3.547^{\mathrm{ab}}$ & $56.00^{\mathrm{ab}}$ \\
\hline CV (\%) & 29.62 & 15.75 & 4.11 & 3.68 & 5.69 & 19.26 \\
\hline
\end{tabular}

$100 \mathrm{C}=100 \%$ calcareous shell; $70 \mathrm{C}=70 \%$ calcareous shell $/ 30 \%$ gravel $; 50 \mathrm{C}=50 \%$ calcareous shell $/ 50 \%$ gravel; $30 \mathrm{C}=30 \%$ calcareous shell $/ 70 \%$ gravel; $10 \mathrm{C}=10 \%$ calcareous shell $/ 90 \%$ gravel, $0 \mathrm{C}=100 \%$ gravel; $\mathrm{NB}=$ no biofilter. Means in the same column followed by different letters differ by Duncan test $(p$ $\leq 0.05)$. CV $(\%)=$ coefficient of variation in percent. 


\section{Conclusion}

Biofilters definitely improve limnological parameters. In addition, all calcareous shell/gravel concentrations kept water conditions at suitable levels for Nile tilapia culture, although morphological parameters (total length, standard length, height and weight) were not affected. Use of $30 \%$ calcareous shell $/ 70 \%$ gravel substrate is highly recommended, as it provided the best nitrification rate during the experiment.

\section{Acknowledgements}

The Foundation for Research Support of the State of Minas Gerais and the National Council for Scientific and Technological Development for financial support. The Development Company of the Valley of the São Francisco and Parnaíba the donation of post-larvae of Nile tilapia.

\section{References}

APHA-AMERICAN PUBLIC HEALTH ASSOCIATION. Standard Methods for the Examination of water and wastewater. 20. ed. Washington DC: USA, 1998, $1220 \mathrm{p}$.

ANDRADE, L.; KUMMER, A. C. B.; FAZOLO, A.; DASMACENO, S.; HASAN, S. D. M. Influência de nitrogênio amoniacal e vazão de ar no processo de nitrificação, etapa de tratamento de efluente de abatedouro de peixe. Engenharia Agrícola, Jaboticabal, v. 30, n. 1, p.160-167, 2010.

BALDISSEROTTO, B. Fisiologia de peixes aplicada à piscicultura. Santa Maria: UFSM, 2002, 212 p.

BOSCOLO, W. R.; HAYASHI, C.; SOARES, C. M.; FURUYA, W. M.; MEURER, F. Desempenho e características de carcaça de machos revertidos de tilápias do Nilo (Oreochromis niloticus), linhagens tailandesa e comum, nas fases inicial e de crescimento. Revista Brasileira de Zootecnia, Brasília, v. 30, n. 5, p. 1391-1396, 2001.

CARDOSO FILHO, R.; CAMPECHE, D. F. B.; PAULINO, R. P. Tilápia em reservatório de água para irrigação e avaliação da qualidade da água. Revista Brasileira de Ciências Agrárias, Recife, v. 5, n. 1, p.117-122, 2010.

CHEN, S. L.; LING, J.; BLANCHETON, J. P. Nitrification kinetics of biofilm as affected by water quality factors. Aquacultural Engineering, Blacksburg Virginia, v. 34, n. 3, p.179-197, 2006.

CRIVELENTI, L. Z.; BORIN, S.; da SILVA, N. R. Piscicultura superintensiva associada à hidroponia em sistema de recirculação de água. Archives of Veterinary Science, Curitiba, v. 14, n. 2, p.109-116, 2009.

FERNANDES, R.; GOMES, L. C.; AGOSTINHO, A. A. Pesquepague: negócio ou fonte de dispersão de espécies exóticas? Acta Scientiarum. Biological Sciences, Maringá, v. 25, n. 1, p. 115120, 2003.

KUBITZA, F. Tilápia: tecnologia e planejamento na produção. Jundiaí: Ed. Copyright, 2000. 289 p.

KUBITZA, F. Qualidade da água no cultivo de peixes e camarões. Jundiaí: São Paulo, 2003, 229 p.

MAINARDES-PINTO, C.S.R.; VERANI, J.R.; ANTONIUTTI, D.M. et al. Estudo comparativo do crescimento de machos de Oreochromis niloticus em diferentes períodos de cultivo. Boletim do Instituto de Pesca, v. 6, p. 19-27, 1989.

MAINARDES-PINTO, C. S. R.; MERCANTE, C. T. J. Avaliação de variáveis limnológicas e suas relações com uma floração de Euglenaceae pigmentada em viveiro povoado com tilápia do Nilo (Oreochromis niloticus Linnaeus). Acta Scientiarum Biological Sciences, Maringá, v. 25, p. 323-328, 2003.

MAXIMIANO, A. A.; FERNANDES, R. O.; NUNES, F. P.; ASSIS, M. P.; MATOS, R. V.; BARBOSA, C. G. S.; OLIVEIRA-FILHO, E. C. Utilização de drogas veterinárias, agrotóxicos e afins em ambientes hídricos: demandas, regulamentação e considerações sobre riscos à saúde humana e ambiental. Ciência e Saúde Coletiva, Manguinhos, v.10, n. 2, p. 481491, 2005.
MERCANTE, C. T. J.; CARMO, C. F.; RODRIGUES, J. C.; OSTI, J. A. S.; MAINARDES-PINTO, C. S.; VAZ-DOS-SANTOS, A. M.; TUCCI, A.; DI GENARO, A. C. Limnologia de viveiro de criação de tilápias do Nilo: avaliação diurna visando boas práticas de manejo. Boletim Instituto da Pesca, São Paulo, v. 37, n. 1, p. 73-84, 2011.

MEURER, F.; HAYASHI, C.; BOSCOLO, W. R. Influência do processamento da ração no desempenho e sobrevivência da tilápia do Nilo durante a reversão sexual. Revista Brasileira Zootecnia, Brasília, DF, v. 32, n. 2, p. 262-267, 2003.

OZÓRIO, R.O.A.; AVNIMELECH, Y.; CASTAGNOLLI, N. Sistemas intensivos fechados de produção de peixes. In: CYRINO, J.E.P.; URBINATI, E.C.; FRACALOSSI, D.M.; CASTAGNOLLI, N. (Ed.). Tópicos especiais em piscicultura de água doce tropical intensiva. São Paulo: TecArt, 2004. p.7-24.

PEDREIRA, M. M. Comparação entre três sistemas no cultivo de larvas de Piracanjuba (Brycon orbignyanus). Revista Ceres, Viçosa, v. 50, n.292, p. 779-786, 2003.

PEDREIRA, M. M.; RIBEIRO, J, S. Efeito de um tipo de biofiltro na larvicultura de pacamã Lophiosilurus alexandri (siluriformes). Agropecuária Técnica, Areia, v. 29, n. 1, p. 5-10, 2008.

PEDREIRA, M. M.; LUZ, R. K.; SANTOS, J. C. E.; SAMPAIO, E. V.; SILVA, R. S. F. Biofiltração da água e tipos de substrato na larvicultura do pacamã. Pesquisa Agropecuária Brasileira, Brasília, DF, v. 44, n. 5, p. 511-518, 2009.

RHIDA, M. T.; CRUZ, E. M. Effect of biofilter media on water quality and biological performance of the Nile tilapia (Oreochromis niloticus L.) reared in a simple recirculating system. Aquacultural Engineering, Virgínia, v. 24, n. 2, p. 157-166, 2001.

ROJAS, N. E. T.; ROCHA, O. Influência da alcalinidade da água sobre o crescimento de larvas de Tilápia do Nilo (Oreochromis niloticus Linnaeus, 1758 Perciformes Cichlidae). Acta Scientiarum Biological Sciences, Maringá, v. 26, n. 2, p. 163-167, 2004.

SAS. Statistical Analises System. User's Guide. Version 6.08, SAS INSTITUTE INC. 4. ed. North Caroline: SAS INSTITUTE INC, 1995, $846 \mathrm{p}$.

SESUK, T., POWTONGSOOK, S., NOOTONG, K. Inorganic nitrogen control in a novel zero-water exchanged aquaculture system integrated with airlift-submerged fibrous nitrifying biofilters. Bioresource Technology, v.100, n. 6, p. 2088-2094, 2009.

SOUZA, M.L.R.; MARANHÃO, T.C.F. Rendimento de carcaça, filé e subprodutos da filetagem da tilápia do Nilo, Oreochromis niloticus (L), em função do peso corporal. Acta Scientiarum, v. 23, p. 897-901, 2001.

TIMMONS, M. B., HOLDER, J. L., EBELIN, J. M. Application of microbead biological filters. Aquacultural Engineering, v. 34, n. 3, p. 332-343, 2006.

VINATEA, L. A. Princípios químicos da qualidade da água em aquicultura: uma revisão para peixes e camarões. 2. ed. Florianópolis: FAPEU UFSC, 2004, 231 p. 